Aminulloh, et al/Jurnal Ekonomi Syariah Teori dan Terapan Vol. 6 No. 4 April 2019: 687-703; DAMPAK PENGUMUMAN KEBIJAKAN BI 7 DAYS REPO RATE PADA SAHAM YANG TERDAFTAR DALAM JAKARTA ISLAMIC INDEX

\title{
DAMPAK PENGUMUMAN KEBIJAKAN BI 7 DAYS REPO RATE PADA SAHAM YANG TERDAFTAR DALAMJAKARTA ISLAMIC INDEX ${ }^{\prime}$
}

\author{
Tisof Amri Izar Aminulloh \\ Departemen Ekonomi Syariah - Fakultas Ekonomi dan Bisnis - Universitas Airlangga \\ Email: tisof.amri.izar.aminulloh-2014@feb.unair.ac.id
}

\section{Ari Prasetyo}

Departemen Ekonomi Syariah - Fakultas Ekonomi dan Bisnis - Universitas Airlangga Email: ari.prasetyo@feb.unair.ac.id

\begin{abstract}
:
This research aims to find out and explain Jakarta Islamic Index market reaction caused by BI 7 Days Repo Rate announcement by Bank Indonesia on April 15th, 2016. The approach used in this research is quantitative approach by using event study method which is the approach that is specialized to analyze a particular event that is believed to have an impact or reaction. Data used is secondary data including announcement data, stock price, trading volume during the period of observation and period of estimation. The object of the research is all the issuer that listed in Jakarta Islamic Index. Period of observation is 31 days started from 15 days before the event date to 15 days after the event date meanwhile the period of estimation is 55 days before period of observation. The focus of the research is to see the reaction shown by the change of Average Abnormal Return and Trading Volume Activity using one sample t-test and paired sample t-test. Data processing used a statistical tool of Stata version 14 by determining level of significance of $5 \%$. The results of the research show that there is a significant average abnormal return around the date of announcement and there is a significant difference in trading volume activity before and after the right issue.

Keywords: BI 7 Days Repo Rate, Sharia Stock, Event Study, Average Abnormal Return, Trading Volume Activity.
\end{abstract}

\section{PENDAHULUAN}

Investasi merupakan serangkaian kegiatan yang dilakukan oleh perusahaan dalam rangka menambah aset yang dapat digunakan di kemudian hari, selain sebagai sarana penambah aset, kegiatan investasi dapat dijadikan sebagai sarana menjadi kerja sama dengan perusahaan lain. Kegiatan investasi pada umumnya dilakukan oleh pihak yang memiliki kelebihan dana atau modal dengan pihak yang membutuhkan dana atau modal, sehingga kegiatan investasi tidak hanya dalam lingkup perusahaan namun juga sampai lingkup terkecil yakni perseorangan.

$$
\text { Sutedi (2011:116) menjelaskan }
$$
investasi menurut definisi adalah menanamkan atau menempatkan aset, baik berupa harta maupun dana, pada sesuatu yang diharapkan akan memberikan hasil pendapatan atau meningkat nilainya di masa depan. Demikian dengan investasi keuangan yang pada dasarnya adalah kegiatan menanamkan dana pada suatu surat berharga yang diharapkan akan meningkat nilainya di masa depan. Investasi keuangan menurut syariah dapat

\footnotetext{
${ }^{1}$ Jurnal ini merupakan bagian dari skripsi Tisof Amri Izar Aminulloh, NIM: 041411431069, yang diuji pada tanggal 13 Juli 2018.
} 
berkaitan dengan kegiatan perdagangan atau kegiatan usaha berupa usaha suatu produk, aset, atau jasa. Namun, investasi keuangan menurut syariah harus terkait secara langsung dengan suatu aset atas kegiatan usaha yang spesifik dan membawa manfaat karena atas manfaat tersebut dapat dilakukan bagi hasil.

Dalam berinvestasi, investor dihadapkan pada berbagai macam sarana investasi, diantaranya adalah sarana investasi melalui instrumen pasar modal dan sarana investasi melalui instrumen perbankan. Dalam UU No. 8 Tahun 1995 tentang Pasar Modal, pasar modal merupakan kegiatan yang berhubungan dengan aktivitas penawaran umum dan perdagangan efek, perusahaan publik yang berkaitan dengan efek yang diterbitkannya, serta lembaga profesi yang berkaitan dengan efek. Apabila seseorang memilih untuk berinvestasi pada pasar modal, investor akan mendapat berbagi macam pilihan instrumen investasi mulai dari saham, reksadana, obligasi, sukuk, dan sebagainya. Selain pasar modal yang bersifat konvensional, indonesia sebagai salah satu negara dengan jumlah penduduk muslim terbesar telah mengembangkan pasar modal syariah sejak tahun 2000 ditandai dengan diluncurkannya indeks harga saham syariah pertama yaitu Jakarta Islamic Index.

Dalam pasar modal Indonesia, terdapat dua indeks saham syariah, yaitu Jakarta Islamic Index (JII) dan Indeks
Saham Syariah Indonesia (ISSI). Jakarta Islamic Index (JII) merupakan indeks yang berisi 30 saham syariah paling aktif dan Indeks Saham Syariah Indonesia (ISSI) merupakan indeks yang berisi seluruh saham syariah yang listing di Bursa Efek. Dalam dunia pasar modal, indeks harga saham merupakan indikator yang menunjukkan pergerakan harga saham. Selain itu, indeks harga saham juga memiliki fungsi sebagai indikator trend pasar yang berarti pergerakan dari indeks harga saham menggambarkan kondisi dari pasar pada waktu tertentu.Hadirnya pasar modal syariah merupakan bukti dari mulai berkembangpesatnya ekonomi islam di indonesia. Sampai tahun 2016, saham syariah sebagai instrumen dalam pasar modal syariah mengalami pertumbuhan yang cukup berarti

Dalam aktivitas berinvestasi di pasar modal, banyak terdapat berbagai peristiwa baik internal maupun eksternal yang sedikit banyak mempengaruhi aktivitas perdagangan instrumen investasi di pasar modal. Peristiwa yang terjadi dapat berupa aksi korporasi yang merupakan tindakan-tindakan bermotif ekonomi yang dilakukan oleh emiten saham dapat juga beberapa peristiwa bersifat makro seperti keadaan perekonomian suatu negara atau kebijakan-kebijakan yang diterapkan oleh suatu negara.

Pada tahun 2016, Bank Indonesia mengeluarkan kebijakan moneter berbasis suku bunga atau yang selama ini dikenal dengan $\mathrm{Bl}$ Rate. Bank Indonesia 
menetapkan kebijakan berupa tidak digunakannya $\mathrm{Bl}$ Rate sebagai suku bunga acuan, melainkan digantikan dengan BI 7 Days Repo Rate. Bank Indonesia menjelaskan bahwa penggunaan $\mathrm{BI} 7$ Days Repo Rate bertujuan untuk mempercepat transmisi kebijakan moneter yang diterapkan dikarenakan BI Rate dinilai lambat direspon oleh pasar dan lembagalembaga keuangan dibawah Bank Indonesia. Langkah untuk mempercepat transmisi kebijakan moneter tersebut adalah dengan mempersingkat tenor atau jangka waktu simpanan bank pada Bank Indonesia yang awalnya selama dua belas hari menjadi paling cepat yujuh hari dan kelipatannya.

Bl Rate merupakan instrumen kebijakan moneter yang ditetapkan oleh Bank Indonesia sebagai institusi pengendali ekonomi disamping tugas utama Bank Indonesia sebagai regulator perbankan dan keuangan di Indonesia. BI Rate atau suku bunga ialah salah satu instrumen yang digunakan oleh Bank Indonesia sebagai pengendali keadaan untuk menjawab tantangan ekonomi. Suku bunga yang ditetapkan oleh Bank Indonesia menjadi acuan bagi seluruh perbankan di Indonesia.

BI 7 Days Repo Rate sebagai pengganti $\mathrm{BI}$ Rate membawa beberapa sifat serta karakteristik yang menawarkan fasilitas baru. Fasilitas baru yang diberikan oleh Bank Indonesia ini berupa ditawarkannya banyak tenor waktu bagi perbankan di pasar kevangan dan pasar repo untuk mengambil dananya kembali. Tujuan dari disediakannya berbagai tenor tersebut adalah untuk mempermudah bank-bank dibawah naungan Bank Indonesia untuk mengelola likuiditasnya. Dengan likuiditas yang baik diharapkan bank-bank tersebut dapat memperlancar penyaluran dana kepada masyarakat untuk mendorong angka pertumbuhan ekonomi yang merupakan salah satu hilir dari kebijakan BI 7 Days Repo Rate. Kebijakan yang dikeluarkan oleh Bank Indonesia berupa penggantian instrumen moneter BI Rate menjadi BI 7 Days Repo Rate dianggap mengandung informasi berupa fokus kinerja ekonomi pemerintah kedepannya untuk mempercepat pengaruh kebijakan suku bunga ke pasar kevangan dan pasar repo perbankan yang ditetapkan dari sebelumnya 12 bulan menjadi lebih banyak variasi hingga tenor terkecilnya yaitu tujuh hari. Kebijakan tersebut juga dinilai menguntungkan bagi perbankan karena memudahkan perbankan dalam mengelola likuidiasnya.

Dihadapkan kepada keadaan seperti tersebut, investor sebagai makhluk ekonomi tentu akan memilih sarana investasi dengan keuntungan yang lebih daripada instrumen lain serta dengan tingkat resiko yang minim. Informasi atas kebijakan tersebut dapat memberikan sinyal bagi para investor dalam mengambil keputusan dalam berinvestasi sehingga dapat menyebabkan perubahan penawaran dan permintaan. Adanya sinyal akan berdempak pada 
lahirnya reaksi pada pasar modal. Reaksi yang terjadi dapat ditunjukkan dengan adanya perubahan average abnormal return di sekitar tanggal pengumuman serta adanya perbedaan Trading volume atau volume perdagangan yang terjadi pada pasar modal, baik konvensional maupun syariah.

Terlepas dari sifat kebijakan BI 7 Days Repo Rate yang menguntungkan sektor perbankan. Keadaan dalam pasar modal juga dapat dipengaruhi oleh variable makroekonomi secara langsung. Dalam penelitian Shumi Akhtar a, Farida Akhtar, Maria Jahromi, Kose John dengan judul "Impact of interest rate surprises on Islamic and conventional stocks and bonds", menunjukkan bahwa perubahan dalam tingkat suku bunga membawa pengaruh terhadap pasar saham dan obligasi baik konvensional maupun syariah. Penelitian tersbut juga diperkuat dengan penelitian selanjutnya yaitu penelitian Mohamed Shikh Albaity dengan judul penelitian "Impact of the Monetary Policy Instruments on Islamic Stock Market Index Return" dengan hasil bahwa instrumen kebijakan moneter berpengaruh terhadap indeks harga saham Islam.

Jakarta Islamic Index (JII) yang merupakan indeks harga saham dalam pasar modal syariah dalam aktivitas perdagangannya pun tidak dapat lepas dari variabel makroekonomi. Dalam penelitian Siti Aliyah yang berjudul "Pengaruh Inflasi Dan Bi Rate Terhadap Indeks Harga Saham Jakarta Islamic Index (JII) Tahun 2012 - 2014" menunjukkan bahwa BI Rate memiliki hubungan positif dan signifikan terhadap Jakarta Islamic Index. Beberapa penelitian diatas mengindikasikan bahwa terdapat hubungan atau pengaruh antara variabel makroekonomi seperti tingkat suku bunga dengan pasar modal, dimana jika terdapat suatu hubungan antara dua variable apabila salah satu mengalami perubahan maka satu lainnya juga akan bereaksi. Berdasarkan sifat kebijakan, BI 7 Days Repo Rate merupakan kebijakan pemerintah dengan skala makro sehingga berpotensi untuk memberikan pengaruh secara makro termasuk Jakarta Islamic Index sebagai sahaln satu indeks harga saham pada pasar modal di indonesia.

Peristiwa pengumuman BI 7 Days Repo Rate tersebut merupakan salah satu peristiwa yang berpotensi untuk mempengaruhi performa bursa di Indonesia tak terkecuali Jakarta Islamic Index sebagai salah satu indeks harga saham yang terdapat dalam bursa Indonesia. Reaksi dapat diakibatkan oleh terpengaruhnya keputusan investasi para investor oleh kandungan informasi yang dimuat dalam peristiwa pengumuman tersebut. Reaksi yang terdapat pada pasar dapat ditunjukkan dengan pergerakan harga dan seberapa banyak saham tersebut diperdagangkan. Pergerakan harga secara fluktuatif akan mempengaruhi return atau tingkat pengembalian yang didapat oleh investor dimana apabila terdapat suatu peristiwa yang mengakibatkan pergerakan harga saham yang tidak seperti biasanya akan 
membuat return yang didapatkan juga tidak seperti biasa. Keadaan tersebut digambarkan sebagai keadaa yang tidak normal, sehingga reaksi suatu pasar dapat diketahui apabila disekitar tanggal peristiwa terdapat abnormal return. Reaksi suatu pasar selain digambarkan dengan abnormal return juga digambarkan dengan adanya perubahan pada volume saham yang diperdagangkan atau Trading Volume Activity (TVA). Perubahan keputusan investasi dari investor memberikan pengaruh terhadap besaran volume saham yang diperdagngankan pada bursa. Berdasarkan latar belakang permasalahan, maka penelitian dimaksudkan untuk mengetahui apakah kandungan informasi dalam pengumuman BI 7 Days Repo Rate oleh Bank Indonesia mempengaruhi reaksi pada pasar Jakarta Islamic Index dengan pendekatan Average Abnormal Return (AAR) dan Trading Volume Activity (TVA) sebagai indikator dan Event Study sebagai metode penelitian. Sehingga rumusan masalah yang akan diangkat adalah sebagai berikut:

1. Apakah terdapat Average Abnormal return pada saham syariah yang terdaftar pada Pasar Jakarta Islamic Index disekitar tanggal pengumuman $\mathrm{BI}$ 7 Days Repo Rate oleh Bank Indonesia?

2. Apakah terdapat perbedaan pendapatan nilai Average Abnormal return pada saham syariah yang terdaftar pada Pasar Jakarta Islamic
Index disekitar tanggal pengumuman BI 7 Days Repo Rate oleh Bank Indonesia?

3. Apakah terdapat perbedaan volume perdagangan atau Trading volume pada saham syariah yang terdaftar pada Pasar Jakarta Islamic Index pasca pengumuman BI 7 Days Repo Rate oleh Bank Indonesia?

\section{LANDASAN TEORI}

Haming dan Basamalah (2010:353) mendefinisikan pasar modal sebagai lembaga keuangan yang menyediakan dana permodalan berjangka panjang, yaitu lebih dari satu tahun. Dalam UU No. 8 Tahun 1995 tentang Pasar Modal, pasar modal adalah kegiatan yang bersangkutan dengan penawaran umum dan perdagangan efek, perusahaan publik yang berkaitan dengan efek yang diterbitkannya, serta lembaga profesi yang berkaitan dengan efek. Pasar modal digunakan oleh pihak yang mengalami defisit atau kekurangan dana untuk mendapatkan dana modal dari pihak eksternal yang mengalami keadaan kelebihan atau surplus dana dan memiliki keinginan untuk melakukan investasi dengan motif untuk mendapatkan keuntungan.

Dalam terbitan Direktorat pasar modal syariah OJK, Sinergi Menuju Pasar Modal Syariah yang Lebih Besar dan Berkembang, 2006, hal 07, Jakarta Islamic Index (JII) adalah indeks saham syariah yang berisi 30 saham syariah yang tercatat dengan rata-rata nilai kapitalisasi terbesar dan nilai likuiditas perdagangan paling tinggi dalam satu tahun terakhir. 
Aminulloh, et al/Jurnal Ekonomi Syariah Teori dan Terapan Vol. 6 No. 4 April 2019: 687-703; DAMPAK PENGUMUMAN KEBIJAKAN BI 7 DAYS REPO RATE PADA SAHAM YANG TERDAFTAR DALAM JAKARTA ISLAMIC INDEX

Bank Indonesia dalam Laporan Tahunan Bank Indonesia Tahun 2016 mendifinisikan BI 7 Days Repo Rate sebagai suku bunga yang mencerminkan sikap atau stance kebijakan moneter bank indonesia dengan acuan transaksi reverse repo rate tenor 7 hari. BI 7 Days Repo Rate merupakan suku bunga acuan baru hasil penguatan kerangka operasi moneter yang memiliki hubungan yang lebih kuat ke suku bunga pasar uang, bersifat transaksional, dan mendorong pendalaman pasar keuangan. Gubernur Bank Indonesia, Agus D.W. Martowardojo dalam siaran pers Bank Indonesia No. 18/29/DKom tertanggal 15 April 2016 menyatakan bahwa bank indonesia mereformulasi suku bunga kebijakan, dari BI Rate menjadi BI 7 Day (Reverse) Repo Rate. Hal ini dilakukan untuk meningkatkan efektivitas transmisi kebijakan moneter. Penguatan operasi moneter ini tidak mengubah sikap dari kebijakan moneter yang sedang diterapkan. Perubahan suku bunga berlaku efektif sejak 19 Agustus 2016 dimana dalam masa transisi sampai dengan sebelum 19 Agustus 2016, Bank Indonesia akan tetap menggunakan BI Rate sebagai suku bunga kebijakan. Dalam periode yang sama, Bank Indonesia akan mulai mengumumkan BI 7 Days Repo Rate sebagai bagian dari suku bunga operasi moneter.

Pengumuman BI 7 Days Repo Rate merupakan kebijakan yang bersifat makro dimana dalam kebijakan ini, Pemerintah yang direpresentasikan oleh Bank
Indonesia hendak mengganti instrumen kebijakan moneter, yaitu BI Rate menjadi BI 7 Days Repo Rate dengan berbagai sifat baru yang disematkan. Suku bunga merupakan salah satu faktor makro ekonomi, dimana faktor makro ekonomi merupakan faktor yang berada di luar perusahaan, tetapi mempunyai pengaruh terhadap kenaikan atau penurunan kinerja perusahaan baik secara langsung maupun secara tidak langsung (Samsul, 2006:200)

Menurut Samsul

(2006:200) perubahan yang terjadi pada faktor makro tersebut tidak akan mempengaruhi kinerja perusahaan secara langsung, malinkan secara perlahan dan bertahap. Namun berbeda dengan harga saham, harga saham akan terpengaruh dengan seketika oleh perubahan faktor makro ekonomi dikarenakan investor memiliki respon dan reaksi yang lebih cepat. Rekasi dapat secara cepat terjadi juga dikarenakan investor dapat mendapatkan informasi dengan cepat pula seiring dengan berkembangnya teknologi telekomunikasi. Informasi akan suatu peristiwa atau kebijakan yang ditetapkan dapat memicu perubahan arah investasi investor yang digambarkan dengan adanya reaksi pada pasar. Pasar akan bereaksi ketika terdapat suatu informasi, dimana adanya informasi membuat efisiensi pasar menjadi setengah kuat. (Samsul, 2006:271) efisiensi pasar dikatakan setengah kuat karena dalam proses pengambilan keputusan jual-beli saham investor menggunakan data harga 
masa lalu, volume masa lalu, dan semua informasi yang dipublikasikan seperti laporan keuangan, laporan tahunan, pengumuman bursa, informasi keuangan internasional, peraturan perundangundangan pemerintah, peristiwa politik, peristiwa hukum, peristiwa sosial, dan lain sebagainya yang dapat mempengaruhi perekonomian nasional.

Sorokina dan Thornton (2016) menunjukkan bahwa inisiasi reformasi keuangan berupa Undang-Undang Dodd Frank memberikan reaksi berupa penurunan resiko sistematis bagi perusahaan kevangan dan perusahaan yang bergantung pada perusahaan kevangan, namun secara bersamaan juga mengakibatkan meningkatnya resiko sistematis bagi perusahaan diluar perusahaan keuangan yaitu perusahaan yang sebagain besar modalnya bergantung pada sumber eksternal. Penelitian tersebut menunjukkan bahwa pasar mengalami reaksi atas suatu perubahan dalam sistem keuangan, sama seperti dengan perubahan yang dilakukan Bank Indonesia dengan mengubah BI Rate menjadi BI 7 Days Repo Rate dengan sifat yang berbeda. Perubahan tersebut memungkinkan pasar modal di Indonesia untuk bereaksi juga.

Pada umumnya investor akan memilih sarana investasi dengan tingkat resiko atau beta yang kecil, sehingga dapat diketahui terdapat cumulative abnormal return pada saat undangundang Dodd Frank dalam masa legislasi. Perubahan BI Rate menjadi BI 7 Days Repo
Rate memungkinkan untuk terjadi reaksi dalam pasar modal karena memberikan fasilitas besaran tingkat moneter dengan berbagai macam tenor. Tingkat moneter yang berbeda dan semakin kecil pada tenor yang pendek menjadi kelamahan perusahaan keuangan bagi investor karena dianggap memberikan tingkat pengembalian yang kecil, namun jumlah tenor yang banyak juga dapat menjadi keuntungan bagi perusahaan karena investor mungkin beranggapan bahwa dengan tenor yang beragam akan memudahkan investor untuk berinvestasi dengan jangka waktu yang singkat. Tidak hanya pasar modal konvensional, namun pasar modal syariah seperti Jakarta Islamic Index juga berpotensi untuk terjadi reaksi. Hal tersebut didukung oleh penelitian Albaity (2011), Akhtar dkk. (2017), Aliyah (2016) dimana pasar modal syariah berhubungan dan bereaksi dengan kebijakan moneter seperti kebijakan suku bunga. Berdasarkan landasan tersebut, maka dapat dirumuskan hipotesis sebagai berikut :

$\mathrm{Hl}$ : Terdapat Average Abnormal Return disekitar tanggal pengumuman BI 7 Days Repo Rate

$\mathrm{H} 2$ : Terdapat perbedaan Average Abnormal Return sebelum dan sesudah pengumuman BI 7 Days Repo Rate

Selain Average Abnormal Return (AAR), reaksi suatu pasar dapat dilihat dari Trading Volume Activity (TVA). Trading Volume Activity (TVA) dapat digunakan untuk melihat apakah lembar saham yang diperdagangkan mengalami 
perubahanan sebelum dan sesudah suatu peristiwa terjadi. Dalam penelitian Cahyanindyah dan Cahyasani (2017) menunjukkan bahwa Trading Volume Activity (TVA) pada saham LQ45 mengalami perubahan atau perbedaan yang signifikan sebelum dan sesudah peristiwa kenaikan BI Rate. Pada peristiwa BI 7 Days Repo Rate, Perubahan juga berpotensi terjadi pada pasar Jakarta Islamic Index dikarenakan beberapa saham pembentuk indeks JII juga tergabung dalam daftar saham pembentuk indeks LQ45. Berdasarkan landasan tersebut, maka dapat dirumuskan hipotesis ketiga sebagai berikut

H3 : Terdapat perbedaan trading volume activity sebelum dan sesudah pengumuman BI 7 Days Repo Rate

\section{METODE PENELITIAN}

Penelitian ini menggunakan pendekatan kuantitatif, yaitu suatu pendekatan dalam penelitian yang menekankan analisisnya pada data-data numerikal (angka) yang dioalh dengan metode statistika. Penelitian kuantitatif digunakan untuk menguji suatu teori, menyajikan sutau fakta atau mendeskripsikan statistik, menunjukkan hubungan antarvariabel dan ada pula yang bersifat mengembangkan konsep, mengembangkan pemahaman, dan mendeskripsikan banyak hal (Wirartha, 2006:140)

Dasar dari penelitian ini adalah teori dan landasan pustaka yang ada serta beberpa penelitiasn terdahulu yang berkaitan dengan masalah yang akan diteliti, kemudian dilanjutkan dengan perumusan masalah yang akan dijawab dan membentuk hipotesis sebagai awal penelitian. Hipotesis dalam penelitian ini adalah adanya dampak dari pengumuman $\mathrm{Bl} 7$ Days Repo Rate terhadap reaksi pasar saham yang termasuk dalam JII, sehingga pendekatan yang digunakan dalam penelitian ini adalah Studi Peristiwa (Event Study).

\section{Definisi Operasional}

BI 7 Days Repo Rate merupakan suku bunga acuan baru hasil penguatan kerangka operasi moneter yang memiliki hubungan yang lebih kuat ke suku bunga pasar vang, bersifat transaksional, dan mendorong pendalaman pasar keuangan.

average abnormal return merupakan rata-rata dari abnormal return dari semua jenis saham yang sedang dianalisis secara harian. Abnormal return adalah selisih antara actual return dan return yang diharapkan yang dapat terjadi sebelum informasi resmi diterbitkan atau telah terjadi kebocoran informasi sasudah informasi resmi diterbitkan. Abnormal return terjadi setiap hari pada setiap jenis saham.

Trading volume activity merupakan suatu instrumen yang dapat digunakan untuk melihat reaksi pasar modal terhadap suatu informasi tertentu. Trading volume activity dapat digunakan untuk melihat apakah investor secara individu menilai suatu peristiwa sebagai sesuatu yang informatif, dalam arti, apakah 
Aminulloh, et al/Jurnal Ekonomi Syariah Teori dan Terapan Vol. 6 No. 4 April 2019: 687-703; DAMPAK PENGUMUMAN KEBIJAKAN BI 7 DAYS REPO RATE PADA SAHAM YANG TERDAFTAR DALAM JAKARTA ISLAMIC INDEX

informasi tersebut akan membuat keputusan investasi yang berbeda dari keputusan investasi normal. Volume perdagangan memiliki peran sebagai indikator liquiditas saham atas suatu informasi yang ada dalam pasar modal. Trading volume activity dapat diukur dengan cara melihat rasio antara jumlah lembar saham yang diperdagangkan pada waktu tertentu dengan jumlah lembar saham yang beredar pada waktu tertentu.

\section{Teknik Analisis}

Untuk membuktikan hipotesis yang diangkat bahwa pengumuman kebijakan BI 7 Days Repo Rate berpengaruh terhadap average abnormal return dan trading volume activity, maka akan dilakukan analisis berdasarkan teori-teori yang mendukung penelitian. Langkahlangkah dalam melakukan teknik analisis sebagai berikut :

1) Mengidentifikasi peristiwa yang akan dijadikan acuan penelitian, yaitu pengumuman BI 7 Days Repo Rate.

2) Menentukan periode pengamatan yang akan digunakan yaitu selama 31 hari dan periode estimasi selama 55 hari sebelum periode pengamatan.

3) Menghitung return tak normal yang terdiri atas pendapatan realisan saham dikurangi pendapatan diharapkan saham.

4) Menghitung TVA.

5) Merumuskan hipotesis

6) Melakukan uji normalitas menggunakan uji normalitas saphirowilk w test
7) Melakukan uji hipotesis yang diangkat.

8) Pengambilan keputusan dan kesimpulan

\section{HASIL PENELITIAN DAN PEMBAHASAN}

Fungsi dari statistik deskriptif adalah untuk memberikan gambaran kepada variabel penelitian secara umum. Analisis yang digunakan dalam penelitian ini adalah nilai rata-rata (mean), standar deviasi, serta nilai minimum dan maksimum.Berikut merupakan tabel hasil statistik deskriptif dari Abnormal Return pada seluruh emiten saham yang menjadi sampel dalam penelitian selama periode pengamatan.

Tabel 1.

Statistik Deskriptif Abnormal Return

\begin{tabular}{|c|c|c|c|c|c|}
\hline Variable & $\begin{array}{c}\text { Ob } \\
\mathrm{s}\end{array}$ & $\begin{array}{c}\text { Mea } \\
\mathrm{n}\end{array}$ & $\begin{array}{c}\text { Std. } \\
\text { Dev. }\end{array}$ & Min & Max \\
\hline $\begin{array}{c}\text { Before } \\
\text { AAR }\end{array}$ & 15 & $\begin{array}{c}- \\
0,18 \%\end{array}$ & $\begin{array}{c}0,66 \\
\%\end{array}$ & $\begin{array}{c}-1,32 \\
\%\end{array}$ & $\begin{array}{c}0,78 \\
\%\end{array}$ \\
\hline $\begin{array}{c}\text { AfterAA } \\
\mathrm{R}\end{array}$ & 16 & $\begin{array}{c}- \\
0,86 \%\end{array}$ & $\begin{array}{c}0,85 \\
\%\end{array}$ & $\begin{array}{c}2,79 \% \\
\%\end{array}$ \\
\hline
\end{tabular}

Berdasarkan tabel 1, pada periode sebelum pengumuman BI 7 Days Repo Rate nilai minimum abnormal return saham sebesar -0,0132567, nilai maksimum saham sebesar 0,0078281 , nilai mean atau ratarata sebesar $-0,0018012$ dengan nilai standar deviasi sebesar 0,0066913. Nilai mean atau rata-rata menunjukkan terjadi abnormal return sebesar 0,0018012. Pada periode setelah pengumuman BI 7 Days Repo Rate, nilai minimum banormal return sebesar -0,0279219, nilai maksimum saham sebesar 0,0082596, nilai mean atau ratarata sebesar $-0,0046902$ dengan standar 
Aminulloh, et al/Jurnal Ekonomi Syariah Teori dan Terapan Vol. 6 No. 4 April 2019: 687-703; DAMPAK PENGUMUMAN KEBIJAKAN BI 7 DAYS REPO RATE PADA SAHAM YANG TERDAFTAR DALAM JAKARTA ISLAMIC INDEX

debiasi sebesar 0,0085361. Nilai mean sebesar -0,0046902 menunjjukan bahwa terjadi abnormal return sebesar -0,0046902 pada periode setelah pengumuman $\mathrm{BI} 7$ Days Repo Rate.

Tabel 2.

Average Abnormal Return Harian

\begin{tabular}{|c|c|c|c|}
\hline Periode & AAR & Periode & AAR \\
\hline$t-15$ & $-0,01061$ & $t+1$ & 0,00588 \\
\hline$t-14$ & $-0,00774$ & $t+2$ & 0,00826 \\
\hline$t-13$ & $-0,00771$ & $t+3$ & $\begin{array}{c}0,00190 \\
2\end{array}$ \\
\hline$t-12$ & $\begin{array}{c}0,00379 \\
6\end{array}$ & $t+4$ & $\begin{array}{c}- \\
0,00067\end{array}$ \\
\hline$t-11$ & $\begin{array}{c}0,00045 \\
5\end{array}$ & $t+5$ & $\begin{array}{c}- \\
0,00387\end{array}$ \\
\hline$t-10$ & $\begin{array}{c}0,00563 \\
7\end{array}$ & $t+6$ & $\begin{array}{c}- \\
0,00734\end{array}$ \\
\hline t-9 & $\begin{array}{c}0,00562 \\
8\end{array}$ & $t+7$ & $\begin{array}{c}- \\
0,01149\end{array}$ \\
\hline t-8 & $-0,00286$ & $t+8$ & $\begin{array}{c}- \\
0,00255\end{array}$ \\
\hline t-7 & $\begin{array}{c}0,00485 \\
9\end{array}$ & $t+9$ & $\begin{array}{c}- \\
0,00395\end{array}$ \\
\hline$t-6$ & $-0,0044$ & $t+10$ & $\begin{array}{c}- \\
0,00625\end{array}$ \\
\hline$t-5$ & $-0,00136$ & $t+11$ & $\begin{array}{c}- \\
0,01485\end{array}$ \\
\hline t-4 & $-0,01327$ & $\dagger+12$ & $\begin{array}{c}- \\
0,00198\end{array}$ \\
\hline$t-3$ & $\begin{array}{c}0,00130 \\
1\end{array}$ & $t+13$ & $-0,0083$ \\
\hline$t-2$ & $\begin{array}{c}0,00782 \\
8\end{array}$ & $\dagger+14$ & $\begin{array}{c}- \\
0,02792\end{array}$ \\
\hline$t-1$ & $-0,00858$ & $\dagger+15$ & $\begin{array}{c}- \\
0,00177\end{array}$ \\
\hline$t-0$ & $-0,00014$ & & \\
\hline
\end{tabular}

average abnormal return dianalisis secara harian dimana periode penagamatn berlangsung selama lima belas hari sebelum pengumuman $\mathrm{BI} 7$ Days Repo Rate dan lima belas hari setelah pengumuman $\mathrm{BI} 7$ Days Repo Rate. Pada periode sebelum pengumuman $\mathrm{BI} 7$ Days Repo Rate terdapat average abnormal return negatif pada $t-15, t-14, t-13, t-8, t-6, t-5, t-4, t-1$. Pada periode setelah pengumuman, AAR negatif juga terjadi pada $t+4, \uparrow+5, \uparrow+6, t+7$, $t+8, t+9, t+10, t+11, t+12, t+13, t+14$, dan $t+15$.

Selama periode pengamatan, average abnormal return mengalami keadaan naik dan turun. Penurunan abnormal return terbesar terjadi pada $t+14$ dengan nilai average abnormal return 0,02792 dimana nilai tersebut turun dari hari sebelumnya sebesar 0,01962. Selain penurunan, kenaikan cukup besar juga terjadi pada ++15 dengan nilai average abnormal return sebesar $-0,00177$ dengan besaran kenaikan dari hari sebelumnya sebesar 0,01962. Keadaan tersebut menggambarkan bahwa reaksi pasar secara dominan terjadi pada periode setelah pengumuman $\mathrm{BI} 7$ Days Repo Rate. Berikut tabel hasil perhitungan Average abnormal return pada periode pengamatan.

Tabel 3.

Statistik Deskriptif Trading Volume Activity

\begin{tabular}{|c|c|c|c|c|c|}
\hline $\begin{array}{c}\text { Variabl } \\
e\end{array}$ & $\begin{array}{c}O \\
\text { bs }\end{array}$ & $\begin{array}{c}\text { Me } \\
\text { an }\end{array}$ & $\begin{array}{c}\text { Std. } \\
\text { Dev. }\end{array}$ & Min. & Max \\
\hline BeforeT & 15 & 0,16 & 0,025 & 0,12 & 0,204 \\
\hline
\end{tabular}


Aminulloh, et al/Jurnal Ekonomi Syariah Teori dan Terapan Vol. 6 No. 4 April 2019: 687-703; DAMPAK PENGUMUMAN KEBIJAKAN BI 7 DAYS REPO RATE PADA SAHAM YANG TERDAFTAR DALAM JAKARTA ISLAMIC INDEX

\begin{tabular}{|c|c|c|c|c|c|}
\hline VA & & $\%$ & $\%$ & $\%$ & $\%$ \\
\hline AfterTV & 16 & 0,14 & 0,029 & 0,095 & 0,205 \\
A & & $\%$ & $\%$ & $\%$ & $\%$ \\
\hline
\end{tabular}

Berdasarkan tabel 3 , pada periode sebelum pengumuman BI 7 Days Repo Rate, nilai minimum dari trading volume activity sebesar 0,0012179 , nilai maksimum sebesar 0,0020409, nilai ratarata (mean) sebesar 0,0016205, serta nilai standar deviasi sebesar 0,0002522. Nilai rata-rata (mean) menunjukkan bahwa rata-rata aktivitas perdagangan atau transaksi saham pada periode sebelum pengumuman BI 7 Days Repo Rate adalah sebesar 0,0016205. Sedangkan pada periode setelah pengumuman $\mathrm{BI} 7$ Days Repo Rate, nilai minimum dari trading volume activity sebesar 0,0009534, nilai maksimum sebesar 0,0020584 , nilai mean atau rata-rata sebesar 0,0014714, serta nilai standar deviasi sebesar 0,0002907. Sama seperti periode sebelum pengumuman, nilai mean pada periode setelah pengumuman menunjukkan bahwa rata-rata aktivitas perdagangan atau transaksi saham pada periode setelah pengumuman BI 7 Days Repo Rate sebesar 0,0014174. Pada penelitian ini, trading volume activity diamati secara harian. Berikut merupakan tabel hasil perhitungan trading volume activity selama periode pengamatan.

\section{Tabel 4.}

\section{Trading Volume Activity Harian}

\begin{tabular}{|c|c|c|c|}
\hline $\begin{array}{c}\text { Period } \\
\text { e }\end{array}$ & TVA & $\begin{array}{c}\text { Periode } \\
\text { Setelah }\end{array}$ & TVA \\
Sebelu & & T. & \\
\hline
\end{tabular}

\begin{tabular}{|c|c|c|c|}
\hline$m$ & & & \\
\hline$t-15$ & 0,001294 & $t-0$ & 0,001377 \\
\hline$t-14$ & 0,001218 & $t+1$ & 0,001518 \\
\hline$t-13$ & 0,001449 & $t+2$ & 0,002058 \\
\hline$t-12$ & 0,001942 & $t+3$ & 0,001992 \\
\hline$t-11$ & 0,002041 & $t+4$ & 0,001744 \\
\hline$t-10$ & 0,001598 & $t+5$ & 0,001282 \\
\hline$t-9$ & 0,001816 & $t+6$ & 0,00119 \\
\hline$t-8$ & 0,001789 & $t+7$ & 0,001484 \\
\hline$t-7$ & 0,001434 & $t+8$ & 0,00141 \\
\hline$t-6$ & 0,001866 & $t+9$ & 0,001192 \\
\hline$t-5$ & 0,001433 & $t+10$ & 0,001262 \\
\hline$t-4$ & 0,001366 & $t+11$ & 0,000953 \\
\hline$t-3$ & 0,001547 & $t+12$ & 0,001336 \\
\hline$t-2$ & 0,001818 & $t+13$ & 0,00154 \\
\hline$t-1$ & 0,001696 & $t+14$ & 0,001599 \\
\cline { 2 - 4 } & & $t+15$ & 0,001605 \\
\cline { 3 - 4 } & & &
\end{tabular}

Berdasarkan tabel 4, pada periode sebelum pengumuman $\mathrm{BI} 7$ Days Repo Rate nilai TVA terendah terjadi pada t-4 dengan rata-rata TVA pada masingmasing emiten sebesar 0,00136, sedangkan TVA dengan nilai maksimum terjadi pada t-13 dengan nilai rata-rata TVA pada masing-masing emiten sebesar 0,001449 . Pada periode setelah pengumuman kenaikan TVA cukup besar terjadi pada $t+2$ dengan nilai rata-rata TVA pada masing-masing emiten sebesar 0,002058, serta pada periode setelah pengumuman BI 7 Days Repo Rate ini, nilai TVA terendah terjadi pada $t+11$ dengan rata-rata TVA pada masing-masing emiten saham sebesar 0,000953 . Pada periode setelah pengumuman, TVA mulai mengalami peningkatan cukup besar di $t+1$ dengan puncak kenaikan tertinggi 
Aminulloh, et al/Jurnal Ekonomi Syariah Teori dan Terapan Vol. 6 No. 4 April 2019: 687-703; DAMPAK PENGUMUMAN KEBIJAKAN BI 7 DAYS REPO RATE PADA SAHAM YANG TERDAFTAR DALAM JAKARTA ISLAMIC INDEX

pada t+2 dengan nilai TVA sebesar 0,002058, dilanjutkan dengan keadaan menurun sampai dengan ++6 .

Sebelum melakukan pengujian terhadap suatu hipotesis, data penelitian harus melewati uji normalitas. Tujuan dari uji normalitas data adalah untuk mengetahui apakah data yang digunakan dalam penelitian telah terdistribusi secara normal. Dalam penelitian ini, uji normalitas yang digunakan adalah uji Saphiro-Wilk normality test. Apabila data telah terbukti terdistribusi dengan normal, maka data dapat diuji secara lanjut dengan uji one sample t-test dan paired sample t-test. Data terbukti terdistribusi dengan normal apabila dalam perhitungan diperoleh nilai signifikan $\geq 0,05$, namun apabila dalam perhitungan diperoleh nilai signifikan $\leq 0,05$ maka data terbukti tidak terdistribusi dengan normal.. Berikut tabel data hasil uji Saphiro-Wilk normality test pada average abnormal return.

Tabel 5.

Uji Normalitas Average Abnormal Return Saphiro-Wilk Normality Test

\begin{tabular}{|c|c|c|c|c|c|}
\hline $\begin{array}{c}\text { Variab } \\
\text { el }\end{array}$ & $\begin{array}{c}\text { Obser } \\
\text { vasi }\end{array}$ & W & V & Z & $\begin{array}{c}\text { Prob } \\
>\text { z }\end{array}$ \\
\hline $\begin{array}{c}\text { Before } \\
\text { AAR }\end{array}$ & 15 & $\begin{array}{c}0,945 \\
78\end{array}$ & $\begin{array}{c}1,0 \\
51\end{array}$ & $\begin{array}{c}0,0 \\
99\end{array}$ & $\begin{array}{c}0,460 \\
64\end{array}$ \\
\hline $\begin{array}{c}\text { AfterA } \\
\text { AR }\end{array}$ & 16 & $\begin{array}{c}0,915 \\
37\end{array}$ & 1,7 & 1,0 & 0,142 \\
71 & 06 \\
\hline
\end{tabular}

Berdasarkan hasil uji Shapiro-Wilk normality test diatas maka dapat disimpulkan bahwa variabel average abnormal return berdistribusi secara normal. Hal tersebut dibuktikan dengan probabilitas kesalahan pada periode sebelum dan sesudah pengumuman $\mathrm{BI} 7$ Days Repo Rate yaitu sebesar 0,46064 dan 0,14206 atau diatas tingkat siginifikansi 0,05 .

Setelah data dinyatakan berdistribusi normal melalui uji normalitas, maka data selanjutnya dapat diuji dengan pengujian one sample t-test. Pengujian dengan menggunakan uji one sample t-test ini bertujuan untuk mengetahui apakah terdapat reaksi dari pasar dimana reaksi ditunjukkan dengan adanya abnormal return pada periode di sekitar tanggal pengumuman $\mathrm{BI} 7$ Days Repo Rate. Berikut merupakan tabel data hasil uji one sample t-test pada variabel average abnormal return.

Tabel 6.

Uji Average Abnormal Return One Sample t-test

\begin{tabular}{|c|c|c|c|c|c|c|}
\hline $\begin{array}{l}\text { Vari } \\
\text { abe } \\
\text { a }\end{array}$ & $\begin{array}{l}\text { O } \\
\text { bs }\end{array}$ & $\begin{array}{l}\text { Mea } \\
\mathrm{n}\end{array}$ & $\begin{array}{l}\text { Std. } \\
\text { Err. }\end{array}$ & $\begin{array}{l}\text { Std. } \\
\text { Dev. }\end{array}$ & $\begin{array}{l}{[95 \%} \\
\text { Con } \\
\text { f. }\end{array}$ & $\begin{array}{l}\text { Inter } \\
\text { val] }\end{array}$ \\
\hline AA & 3 & $\begin{array}{l}- \\
0,00 \\
3292 \\
3\end{array}$ & $\begin{array}{l}0,00 \\
1385 \\
2\end{array}$ & $\begin{array}{l}0,00 \\
7712 \\
4\end{array}$ & $\begin{array}{l}- \\
0,00 \\
6121 \\
2\end{array}$ & $\begin{array}{l}- \\
0,00 \\
0463 \\
3\end{array}$ \\
\hline \multicolumn{3}{|c|}{$\begin{array}{l}\text { mean }=\text { mean } \\
(A A R)\end{array}$} & & & \multicolumn{2}{|c|}{$t=-2,3768$} \\
\hline \multicolumn{3}{|c|}{ Ho: mean $=0$} & & & \multicolumn{2}{|c|}{$\begin{array}{l}\text { degrees of } \\
\text { freedom = } \\
30\end{array}$} \\
\hline
\end{tabular}




\begin{tabular}{|c|c|c|}
\hline Ha: mean $<0$ & $\begin{array}{l}\text { Ha: mean } \\
!=0\end{array}$ & \\
\hline $\begin{array}{l}\operatorname{Pr} \quad(T<t)= \\
0,0120\end{array}$ & $\begin{array}{l}\operatorname{Pr}(|T|> \\
|\dagger|)= \\
0,0240\end{array}=$ & $\begin{array}{l}>0 \\
\operatorname{Pr}(T>t) \\
0,9880\end{array}$ \\
\hline
\end{tabular}

Berdasarkan tabel diatas, hasil perthitungan menunjukkan bahwa nilai probabilitas $\operatorname{Pr}(T<t)<0$ yaitu sebesar 0,0120 atau memenuhi kurang dari 0,05 yang menunjukkan bahwa $\mathrm{HO}$ ditolak dan $\mathrm{Ha}$ diterima. Hasil tersebut menunjukkan bahwa terdapat abnormal return atas pengujian reaksi pasar disekitar periode pengumuman BI 7 Days Repo Rate oleh Bank Indonesia. Hasil perhitungan menunjukkan nilai signifikan 0,0120 berada pada mean < 0 dimana hal tersebut menunjukkan bahwa nilai signifikansi berada pada wilayah nilai mean kurang dari 0 atau nilai mean negatif.

Pengujian melalui uji paired sample t-test ini bertujuan untuk mengetahui apakah terdapat perbedaan average abnormal return pada periode sebelum dan sesudah peristiwa pengumuman BI 7 Days Repo Rate oleh Bank Indonesia. Berikut merupakan tabel hasil perhitungan dengan menggunakan uji paired sample t-test pada variabel average abnormal return dengan menggunakan Stata ver. 14.

\section{Tabel 7.}

\section{Uji Average Abnormal Return}

Paired Sample t-Test

\begin{tabular}{|c|l|l|l|l|l|l|}
\hline Vari & $\begin{array}{l}\text { O } \\
\text { able }\end{array}$ & $\begin{array}{l}\text { Me } \\
\text { an }\end{array}$ & $\begin{array}{l}\text { Std. } \\
\text { Err. }\end{array}$ & $\begin{array}{l}\text { Std. } \\
\text { Dev. }\end{array}$ & $\begin{array}{l}{[95} \\
\%\end{array}$ & $\begin{array}{l}\text { Inter } \\
\text { val] }\end{array}$ \\
\hline
\end{tabular}

\begin{tabular}{|c|c|c|c|c|c|c|}
\hline & & & & & f. & \\
\hline $\begin{array}{l}\text { After } \\
\text { AAR }\end{array}$ & $\begin{array}{l}1 \\
5\end{array}$ & $\begin{array}{l}- \\
0,00 \\
4884 \\
7\end{array}$ & $\begin{array}{l}0,00 \\
2271 \\
9\end{array}$ & $\begin{array}{l}0,00 \\
8798 \\
9\end{array}$ & $\begin{array}{l}- \\
0,00 \\
9757 \\
3\end{array}$ & $\begin{array}{l}- \\
0,00 \\
0012\end{array}$ \\
\hline $\begin{array}{l}\text { Befo } \\
\text { reAA } \\
\text { R }\end{array}$ & $\begin{array}{l}1 \\
5\end{array}$ & $\begin{array}{l}- \\
0,00 \\
1801 \\
2\end{array}$ & $\begin{array}{l}0,00 \\
1727 \\
7\end{array}$ & $\begin{array}{l}0,00 \\
6691 \\
3\end{array}$ & $\begin{array}{l}- \\
0,00 \\
5506 \\
7\end{array}$ & $\begin{array}{l}0,00 \\
1904 \\
3\end{array}$ \\
\hline diff & 5 & $\begin{array}{l}- \\
0,00 \\
3083 \\
5\end{array}$ & $\begin{array}{l}0,00 \\
2647 \\
6\end{array}$ & 0254 & $\begin{array}{l}0,00 \\
8761 \\
9\end{array}$ & $\begin{array}{l}0,00 \\
2595\end{array}$ \\
\hline \multicolumn{3}{|c|}{$\begin{array}{l}\text { mean(diff) } \\
\text { mean } \\
\text { (AfterAAR } \\
\text { BeforeAAR) }\end{array}$} & & & \multicolumn{2}{|c|}{$t=-1,1647$} \\
\hline \multicolumn{3}{|c|}{$\begin{array}{l}\text { Ho: mean(diff) } \\
=0\end{array}$} & & & \multicolumn{2}{|c|}{$\begin{array}{l}\text { degrees of } \\
\text { freedom = } \\
14\end{array}$} \\
\hline \multicolumn{3}{|c|}{$\begin{array}{l}\text { Ha: mean(diff) } \\
<0 \\
\operatorname{Pr}(T<\dagger)=0,1318\end{array}$} & \multicolumn{2}{|c|}{$\begin{array}{l}\text { Ha: } \\
\text { mean(diff) } \\
!=0 \\
\operatorname{Pr}(|\mathrm{T}|> \\
|\dagger|)= \\
0,2636\end{array}$} & \multicolumn{2}{|c|}{$\begin{array}{l}\text { Ha: } \\
\text { mean(diff) } \\
>0 \\
\operatorname{Pr}(T>H)= \\
0,8682\end{array}$} \\
\hline
\end{tabular}

Berdasarkan hasil perhitungan diatas, diperoleh nilai probabilitas $\operatorname{Pr}(T<\dagger)$ $<0$ sebesar 0,1318 dan nilai probabilitas $\operatorname{Pr}(\mathrm{T}>\dagger)>0$ sebesar 0,8682 dimana hasil dari keduanya lebih dari 0,05. Hasil hitung yang berada pada lebih dari 0,05 menunjukkan bahwa $\mathrm{HO}$ diterima dan $\mathrm{Ha}$ ditolak dimana hasil tersebut menunjukkan bahwa tidak terdapat perbedaan average abnormal return baik sebelum 
Aminulloh, et al/Jurnal Ekonomi Syariah Teori dan Terapan Vol. 6 No. 4 April 2019: 687-703; DAMPAK PENGUMUMAN KEBIJAKAN BI 7 DAYS REPO RATE PADA SAHAM YANG TERDAFTAR DALAM JAKARTA ISLAMIC INDEX

dan sesudah pengumuman BI 7 Days Repo Rate.

\section{Tabel 8.}

Uji NormalitasTrading Volume Activity Saphiro-Wilk Normality Test

\begin{tabular}{|c|c|c|c|c|c|}
\hline $\begin{array}{c}\text { Variab } \\
\text { el }\end{array}$ & $\begin{array}{c}\text { Obser } \\
\text { vasi }\end{array}$ & W & V & Z & $\begin{array}{c}\text { Prob } \\
>z\end{array}$ \\
\hline $\begin{array}{c}\text { Before } \\
\text { AAR }\end{array}$ & 15 & $\begin{array}{c}0,957 \\
38\end{array}$ & $\begin{array}{c}0,8 \\
26\end{array}$ & $\begin{array}{c}0,3 \\
77\end{array}$ & $\begin{array}{c}0,646 \\
98\end{array}$ \\
\hline $\begin{array}{c}\text { AfterA } \\
\text { AR }\end{array}$ & 16 & $\begin{array}{c}0,962 \\
46\end{array}$ & $\begin{array}{c}0,7 \\
61\end{array}$ & $\begin{array}{c}0,5 \\
44\end{array}$ & $\begin{array}{c}0,706 \\
63\end{array}$ \\
\hline
\end{tabular}

Berdasarkan hasil uji Shapiro-Wilk normality test diatas maka dapat disimpulkan bahwa variabel trading volume activity berdistribusi secara normal dan dapat divji secara uji parametrik. Hal tersebut dibuktikan dengan probabilitas kesalahan pada periode sebelum dan sesudah pengumuman $\mathrm{BI} 7$ Days Repo Rate yaitu sebesar 0,64698 dan 0,70663 atau diatas tingkat siginifikansi 0,05.

Tabel 9.

Uji Trading Volume Activity

Paired Sample t-Test

\begin{tabular}{|c|c|c|c|c|c|c|}
\hline $\begin{array}{l}\text { Vari } \\
\text { able }\end{array}$ & $\begin{array}{l}\text { O } \\
\text { b } \\
\text { s. }\end{array}$ & $\begin{array}{l}\text { Me } \\
\text { an }\end{array}$ & $\begin{array}{l}\text { Std. } \\
\text { Err. }\end{array}$ & $\begin{array}{l}\text { Std. } \\
\text { Dev. }\end{array}$ & $\begin{array}{l}95 \\
\% \\
\text { Con } \\
\text { f. }\end{array}$ & $\begin{array}{l}\text { Inter } \\
\text { val] }\end{array}$ \\
\hline $\begin{array}{l}\text { Afte } \\
\text { rTVA }\end{array}$ & 5 & $\begin{array}{l}0,00 \\
1462 \\
5\end{array}$ & $\begin{array}{l}0,00 \\
0077 \\
1\end{array}$ & $\begin{array}{l}0,00 \\
0298 \\
6\end{array}$ & $\begin{array}{l}0,00 \\
1297 \\
2\end{array}$ & $\begin{array}{l}0,00 \\
1627 \\
9\end{array}$ \\
\hline $\begin{array}{l}\text { Befo } \\
\text { reTV } \\
\text { A }\end{array}$ & 5 & $\begin{array}{l}0,00 \\
1620 \\
5\end{array}$ & $\begin{array}{l}0,00 \\
0065 \\
1\end{array}$ & $\begin{array}{l}0,00 \\
0252 \\
2\end{array}$ & $\begin{array}{l}0,00 \\
1480 \\
8\end{array}$ & $\begin{array}{l}0,00 \\
1760 \\
1\end{array}$ \\
\hline diff & 1 & - & 0,00 & 0,00 & 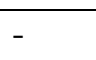 & 0,00 \\
\hline
\end{tabular}

\begin{tabular}{|c|c|c|c|c|c|}
\hline 5 & $\begin{array}{l}0,00 \\
0157 \\
9\end{array}$ & $\begin{array}{l}0086 \\
1\end{array}$ & $\begin{array}{l}0333 \\
3\end{array}$ & $\begin{array}{l}0,00 \\
0342 \\
5\end{array}$ & $\begin{array}{l}1760 \\
1\end{array}$ \\
\hline $\begin{array}{l}\text { mean/dif } \\
\text { mean (A } \\
\text { - BeforeT }\end{array}$ & $\begin{array}{l}\quad= \\
\text { erTVA } \\
\text { A) }\end{array}$ & & & \multicolumn{2}{|c|}{$t=-1,8353$} \\
\hline $\begin{array}{l}\text { Ho: me } \\
=0\end{array}$ & n(diff) & & & \multicolumn{2}{|c|}{$\begin{array}{l}\text { degrees of } \\
\text { freedom=1 } \\
4\end{array}$} \\
\hline $\begin{array}{l}\text { Ha: me } \\
<0 \\
\operatorname{Pr}(\mathrm{T} \quad< \\
0,0439\end{array}$ & $\begin{array}{l}\text { n(diff) } \\
\text { †) = }\end{array}$ & $\begin{array}{l}\text { Ha: } \\
\text { mean } \\
!=0 \\
\operatorname{Pr}(\mid \\
|\dagger|) \\
0,0878\end{array}$ & $\begin{array}{r}\text { T| } \\
=\end{array}$ & $\begin{array}{l}\text { Ha: } \\
\text { mear } \\
>0 \\
\operatorname{Pr}(T \\
0,956\end{array}$ & $\begin{array}{l}\text { (diff) } \\
\dagger)=\end{array}$ \\
\hline
\end{tabular}

Diperoleh nilai probabilitas $\operatorname{Pr}(T<\dagger)$ $<0$ sebesar 0,0439. Hasil hitung yang berada pada kurang dari 0,05 menunjukkan bahwa $\mathrm{HO}$ ditolak dan $\mathrm{Ha}$ diterima dimana hasil tersebut menunjukkan bahwa terdapat perbedaan trading volume activity pada periode sebelum dan sesudah pengumuman $\mathrm{BI} 7$ Days Repo Rate.

\section{PEMBAHASAN}

Pengaruh Pengumuman BI 7 Days Repo

Rate terhadap Average Abnormal Return.



Gambar 1.

Grafik Average Abnormal Return Harian 
Aminulloh, et al/Jurnal Ekonomi Syariah Teori dan Terapan Vol. 6 No. 4 April 2019: 687-703; DAMPAK PENGUMUMAN KEBIJAKAN BI 7 DAYS REPO RATE PADA SAHAM YANG TERDAFTAR DALAM JAKARTA ISLAMIC INDEX

Adanya abnormal return yang signifikan secara statistik disekitar tanggal peristiwa merupakan wujud dari adanya reaksi dari pasar atas peristiwa pengumuman kebijakan BI 7 Days Repo Rate oleh Bank Indonesia. Selain itu, adanya uji paired sample t-test pada average abnormal return yang menunjukkan semakin turunnya rata-rata AAR setelah pengumuman juga merupakan bentuk reaksi dari pasar meskipun tidak terbukti secara statistik terdapat perbedaan AAR sebelum dan sesudah pengumuman.Reaksi yang ditunjukkan oleh pasar menggambarkan bahwa pasar tidak menganggap peristiwa pengumuman $\mathrm{Bl} 7$ Days Repo Rate sebagai berita baik.

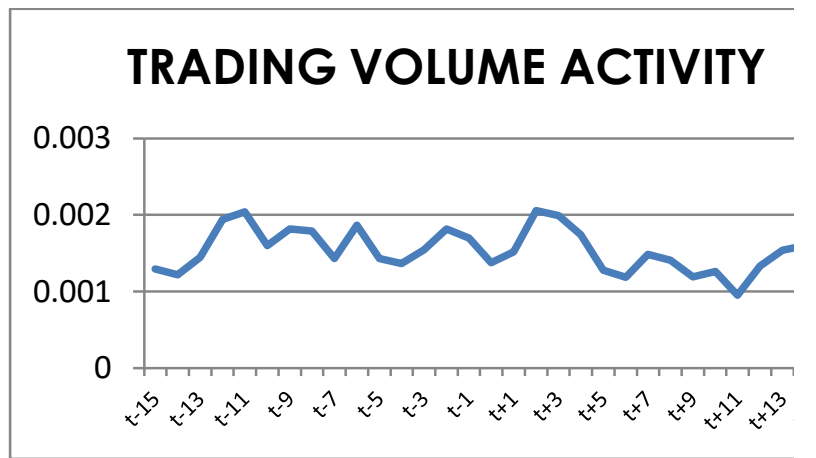

Gambar 2.

\section{Grafik Trading Volume Activity Harian}

Trading Volume Activity (TVA) menggambarkan intensitas aktivitas perdangangan saham di pasar modal. Peristiwa pengumuman $\mathrm{BI} 7$ Days Repo Rate direspon pasar dengan menurunnya rata-rata trading volume activity pada periode setelah pengumuman dibanding dengan periode sebelum pengumuman, menurunnya intensitas perdagangan saham tersebut menunjukkan bahwa investor kurang menggemari untuk bertransaksi pada saham sehingga perdagangan saham menjadi kurang aktif atau lesu. Namun perdagangan saham sangat aktif terekam pada t+2 dengan ditunjukkan oleh grafik yang melonjak dari hari sebelumnya. Aktivitas perdagangan para investor juga ditentukan oleh harga dan return saham pada saat itu. Sejalan dengan hasil data padda average abnormal return, pada periode periode setelah pengumuman, AAR terus bergerak turun sampai titik terendahnya pada $t+14$, trading volume activity juga bergerak turun yang artinya investor yang memegang saham memilih untuk tidak melepas saham meski keadaan harga saham menurun untuk menunggu keadaan memulih. Namun AAR terus beregerak turun sampai titik terendah pada $t+14$ sehingga investor menyikapi dengan melepas saham yang mereka miliki sehingga angka saham yang diperdagangkan atau intensitas investor memperdagangkan mengalami kondisi naik mulai pada $t+12$. Tindakan melepas saham yang dimiliki adalah usaha investor untuk menghindari kerugian berupa capital loss yang lebih besar lagi.

Adanya reaksi pasar atas pengumuman Bl 7 Days Repo Rate oleh Bank Indonesia yang ditunjukkan oleh perbedaan Trading Volume Activity ini menunjukkan bahwa pengumuman $\mathrm{BI} 7$ Days Repo Rate mengandung informasi yang merupakan sinyal buruk untuk kegiatan pasar modal. Reaksi buruk yang ditimbulkan oleh investor diakibatkan oleh 
melemahnya harga saham akibat dari adanya peristiwa pengumuman kebijakan BI 7 Days Repo Rate yang dinilai telah mempengaruhi preferensi investor dalam berinvestasi. Hal ini menunjukkan investor menjadikan suku bunga sebagai salah satu pertimbangan dalam menentukan keputusan investasinya. Keadaan tersebut menggambarkan bahwa investor yang berinvestasi pada saham yang terdaftar dalam Jakarta Islamic Index belum sepenuhnya merupakan investor yang menerapkan prinsip syariah dalam berinvestasi melainkann investor yang masih terpaku pada tujuan untuk mencari keuntungan

\section{SIMPULAN}

Hasil penelitian menunjukkan bahwa peristiwa pengumuman kebijakan BI 7 Days Repo Rate berpengaruh secara signifikan terhadap Average Abnormal Return dan Trading Volume Activity pada pasar Jakarta Islamic Index.

\section{DAFTAR PUSTAKA}

Akhtar, dkk. 2017. Impact of interest rate surprises on Islamic and conventional stocks and bonds.Elsevier Ltd. Journal of International Money and Finance 79 (2017) 218-231

Albaity, Mohamed. 2011. Impact of the Monetary Policy Instruments on Islamic Stock Market Index Return. Discussion Paper No. 2011-26| July 18, $2011 . h t t p: / / w w w . e c o n o m i c s-$ ejournal.org/economics /discussio np a pers/2011-26
Aliyah, Siti. 2016. Pengaruh Inflasi Dan Bi Rate Terhadap Indeks Harga Saham Jakarta Islamic Index (Jii) Tahun 2012 - 2014. Salatiga. Fakultas Ekonomi dan Bisnis Islam IAIN Salatiga

Bank Indonesia. 2017. Laporan Tahunan 2016:Mengoptimalkan Potensi, Memperkuat Reseliensi. Jakarta: Bank Indonesia (www.bi.gi.id)

Burhanuddin. 2008. Pasar Modal Syariah (Tinjauan Hukum). Yogyakarta: UII Press

Cahyaningdyah dan Cahyasani. 2017. Analisis Reaksi Pasar Modal Atas Pengumuman Kenaikan Bi Rate Tanggal 12 November 2013. Semarang. Jurnal Maksipreneur, Vol. VI, No. 2, Juni 2017, hal. 56 - 65

Dewan Syariah Nasional. 2004. Fatwa DVN No. 40/DSN-MUI/X/2003 tentang Pasar Modal dan Pedoman Umum Penerapan Prinsip Syariah di Bidang Pasar Modal (online) (http://www.dsnmui.or.id, diakses pada 2 Februari 2018)

Fahmi, Irham. 2006. Analisis Investasi dalam Perspektif Ekonomi dan Politik. Bandung: PT Refika Aditama

Halim, Abdul. 2015. Analisis Investasi dan Aplikasinya: Dalam Aset Keuangan dan Aset Riil. Jakarta: Salemba Empat

Haming dan Basamalah. 2010. Studi Keelayakan Investasi Proyek dan Bisnis. Jakarta: Bumi Aksara

Hartono, Jogiyanto. (2009). Teori Portofolio dan Analisis Investasi. Edisi Keenam. 
Yogyakarta: BPFE Universitas Gajah Mada. 2015. Studi Peristiwa: Menguji Reaksi Pasar Modal Akibat Suatu Peristiwa. Yogyakarta: BPFEYogyakarta

Huda dan Nasution. 2007. Investasi Pada Pasar Modal Syariah. Jakarta: Kencana

Manan, Abdul. 2012. Hukum Ekonomi Syariah : Dalam Perspektif Kewenangan Peradilan Agama. Jakarta: Kencana Prenadamedia Group

Samsul, Mohammad. 2006. Pasar Modal dan Manajemen Portofolio. Jakarta: Erlangga

Sharpe, William F. 1999. Investasi. Jakarta: Preanhallindo

Sorokina dan Thornton. 2016. Reactions of equity markets to recent financial reforms. Elsevier Inc. Journal of Economics and Business 87 (2015) 50-69

Sutedi, Adrian. 2011. Pasar Modal Syariah: Sarana Investasi Keuangan Berdasarkan Prinsip Syariah. Jakarta: Sinar Grafika

Tandelilin, Eduardus. (2010). Analisis Investasi dan Manajemen Protofolio.Yogyakarta: BPFE Fakultas Ekonomi UGM.

Ulfah, Rizkia. 2011. Pengaruh Variabel Makroekonomi Terhadap Penetapan Nisbah Bagi Hasil Deposito Mudharabah Perbankan Syariah Di Indonesia. Jakarta:
Fakultas Syariah dan Hukum UIN Syarif Hidayatullah

Warjiyo dan Solikin. 2003. Kebijakan Moneter di Indonesia. Jakarta: Pusat Pendisikan Dan Studi Kebanksentralan (PPSK)

Wirartha, I. 2006. Metodologi Penelitian Sosial Ekonomi. Yogyakarta: C.V Andi Offset. 